\title{
The Nigerian Education Milieu in the SDG Era: The Roles, Values, Challenges and Prospects of ODL and Lifelong Learning
}

\author{
Adeyinka Olumuyiwa Osunwusi \\ Department of Educational Foundations, Faculty of Education, \\ National Open University of Nigeria (NOUN) \\ 14-16 Ahmadu Bello Way, Victoria Island, Lagos, Nigeria. \\ E-mail: aosunwusi@yahoo.com
}

Tel: +234-8029797493; +234-8067461324

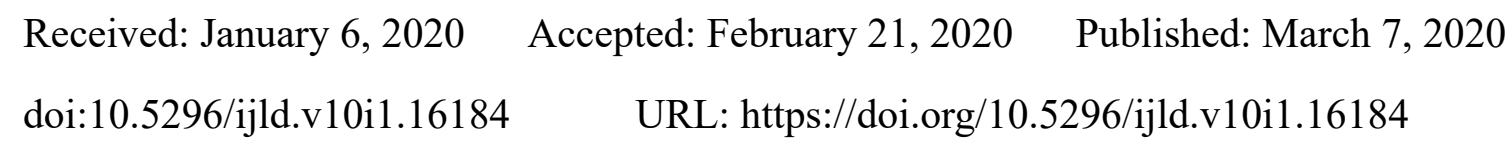

\begin{abstract}
National governments are under increasing pressures to address issues surrounding sustainable development. Interestingly, considerable attention is shifting towards education, which has been widely recognized not only as a fundamental human right but also as a catalyst for sustainable development and a vehicle for confronting the challenges facing societies in terms of profound shifts in demographics as well as socio-economic, environmental and ecological realities. As a corollary, ODL and lifelong learning have equally been identified as constituting a force contributing to social and economic development. As a member of the United Nations, Nigeria is committed to achieving not only the human rights enshrined in the Universal Declaration of Human Rights of 1948 but also the Global Goals, especially SDG 4 on equitable quality education. This paper examines the UNESCO Sustainable Development Goals and explores, based on a review of extant literature, the conceptual and theoretical dimensions of ODL and lifelong learning in the context of their role, values, challenges and opportunities. The paper also outlines current trends in the context of the Nigerian education system and suggests policy, strategy and institutional considerations for mainstreaming ODL and lifelong learning for the purpose of achieving SDG 4. The review of related literature included a search of both published and conference papers and deployed systematic procedures for an exploration of perspectives and ideologies on the key issues of the Global Goals, sustainable development, education for sustainable development (ESD), ODL, and lifelong learning. The
\end{abstract}


study revealed that while the Global Goals are enjoying increasing buy-ins, progress towards achieving the SDGs - particularly Goal 4 - has been unimpressive in many countries, particularly in sub-Saharan Africa. The study also identified trends, challenges and opportunities for integrating ESD in education, ODL and lifelong learning in Africa in general and Nigeria in particular. Based on an evaluation and analysis of perspectives, the study concluded that Nigeria is still a long way to achieving the SDGs. A number of suggestions were made towards a reasonable achievement of sustainable development goal 4, including the importance of: strengthening relevant constitutional framework on education; providing supportive policy and institutional frameworks; and integrating the philosophies of sustainable development in education and training at all levels.

Keywords: Lifelong learning, ODL, Sustainable Development Goals, SDG 4, education.

\section{Introduction}

National governments are under increasing pressures to address issues surrounding sustainable development. Interestingly, considerable attention is shifting towards education, which has been widely recognized not only as a fundamental human right but also as a catalyst for sustainable development (SD) and a vehicle for confronting the challenges facing societies in terms of profound shifts in demographics as well as socio-economic, environmental and ecological realities. As a corollary, open and distance learning (ODL) and lifelong learning (LLL) have equally been identified as constituting a force contributing to social and economic development. As a member of the United Nations, Nigeria is committed to achieving not only the human rights enshrined in the Universal Declaration of Human Rights (UDHR) of 1948 but also the Global Goals embodied in the UNESCO Sustainable Development Goals, especially Goal 4 (SDG 4), which emphasizes equitable quality education.

Nigeria's commitment is clearly reflected in a number of legal, policy, and methodological frameworks, albeit some of these frameworks have exhibited more glamour in terms of their theatricality than practicability. For example, Chapter II of the Constitution of the Federal Republic of Nigeria (CFRN) 1999, as amended, deals with the Fundamental Objectives and Directive Principles of State Policy which, although effectively non-justiciable and, therefore, legally unenforceable, impose obligations on the State in terms of a number of educational, political, socio-economic, foreign policy, environmental and cultural objectives. Section 18 of the 1999 Constitution specifically enjoins the State to direct its policy towards ensuring: equal and adequate educational opportunities at all levels; the promotion of science and technology; the eradication of illiteracy; and the provision of free, compulsory and universal primary education, free university education, and free adult literacy programmes.

The National Policy on Education (NPE) of 1977 also proffers far-reaching policy directions for expanding and strengthening the Nigerian education space, while the revised NPE 2013 declares that mass literacy programme shall be provided free by government to beneficiaries. According to Jegede (2016), the NPE 1977 recognized the ODL system as a distinct sector of education by emphasizing that "maximum efforts will be made to enable those who can benefit from higher education to be given access to it. Such access may be through universities or correspondence courses, or open universities, or part-time and work study programme" (p. 6). 


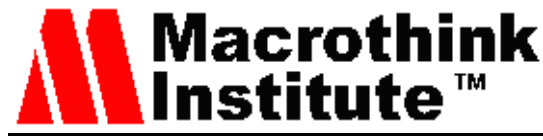

International Journal of Learning and Development

ISSN 2164-4063 2020, Vol. 10, No. 1

The Abuja Declaration on the 2001-2010 Decade of Distance Education in Nigeria on 29 September 2000, also, pledged the adoption of distance education as a desirable and inevitable mode of providing access to all and achieving equitable representation by removing the distance from education.

There are also a number of programmes and policies aimed at promoting education, including: the Revised National Policy on Education, 2013; the Nomadic Education Programme; the National Policy on Gender in Basic Education (2006); the Federal Teachers' Scheme, established in 2006 with the aim of tackling the acute shortage of qualified primary and junior secondary school teachers; the Almajiri Education Programme, which integrates the Quranic/Almajiri system into basic education; and the Universal Education Policy.

The potential of education in terms of promoting and assuring environmental, economic, and social sustainability has been widely recognized. There is growing awareness that education can play a key role in tackling the challenges of the $21^{\text {st }}$ century (Madsen, 2013). Goodier (2017, p. 235) reiterates that the "key role of education in societal and economic development is recognized in the right to primary education forming part of many international statements on human rights". Education is also seen as the first step of sustainable development and a very important step in enhancing a generation of people to understand the importance of sustainability (Zenelaj, 2013). As reaffirmed at the UN Conference on Sustainable Development (Rio+20), "full access to quality education at all levels is an essential condition for achieving sustainable development, poverty eradication, gender equality and women's empowerment, as well as human development, for the attainment of the internationally agreed development goals, including the Millennium Development Goals, and for the full participation of both women and men, in particular young people" (United Nations, 2012, para 229). Okebukola (2013) catalogues the contributory role of education in bolstering the economy of a nation as including: developing skills and knowledge for growing the economy and spawning new industries; promoting creativity; engendering research for new inventions; reducing poverty; advancing gender equality; and promoting health.

Given what has been termed "the systemic nature of educational change and of human development" (Torres, 2003, p.17), the main purpose of education is transferring global values to individuals (Ates \& Alsal, 2012). The World Conference on Education for All (WCEFA), held in Jomtien, Thailand from $5^{\text {th }}$ to $9^{\text {th }}$ March 1990, expressed, in the Preamble to the World Declaration on Education for All (Meeting Basic Learning Needs), the understanding "that education can help ensure a safer, healthier, more prosperous and environmentally sound world, while simultaneously contributing to social, economic, and cultural progress, tolerance, and international cooperation" (WCEFA Inter-Agency Commission, 1990).

The implication, therefore, is that education, when appropriately packaged and implemented, is an indispensable key to achieving the Global Goals. The following remark by Gro Harlem Brundtland in the Foreword to "Our Common Future" is highly instructive:

Unless we are able to translate our words into a language that can reach the minds and hearts of people young and old, we shall not be able to undertake the extensive social changes needed to correct the course of development (Brundtland Commission, 1987, Chairman's Foreword). 
This paper examines the UNESCO Sustainable Development Goals (SDGs) within the perspectives of sustainable development and sustainable education and with an emphasis on Sustainable Development Goal 4 (SDG 4) on equitable quality education. It explores the conceptual and theoretical dimensions of ODL and lifelong learning in the context of their roles, values, challenges and prospects in relation to the Nigerian education realm in particular. It also identifies and outlines current trends in the context of the Nigerian education system vis-à-vis the stride towards achieving SDG 4 and ends with a number of suggestions in respect of policy, strategy and institutional considerations for mainstreaming ODL and lifelong learning in Nigeria with a view to achieving the global sustainable development goals, particularly goal number 4 (SDG 4).

\section{The Global Goals and SDG4}

The UNESCO Sustainable Development Goals (SDGs), or the Global Goals, which came into effect in January 2016 following their adoption by the UN summit of world leaders in New York on 25 September 2015, serve as a seamless transition from the 15-year Millennium Development Goals (MDGs), which embodied six fundamental values, namely: freedom, equality, solidarity, tolerance, respect for nature, and shared responsibility (OSSAP-MDGs, 2015) and eight time-bound goals with a 2015 deadline, namely: Eradicate extreme poverty and hunger, Achieve universal primary education, Promote gender equality and empower women, Reduce child mortality, Improve maternal health, Combat HIV and AIDS, malaria and other diseases, Ensure environmental sustainability, and Develop a global partnership for development.

The SDGs are a set of objectives within a universal agreement to end poverty, protect all that makes the planet habitable, and ensure that all people enjoy peace and prosperity, now and in the future (Morton et al, 2017). Aside from being based on the proposal for SDGs developed by the Open Working Group of the UN General Assembly on SDGs, the global goals are a consequence of years of high-level global summits, discourses, and conferences. Table 1 presents some of the events relevant to sustainable development (SD) and education for sustainable development (ESD).

The 15-year SDGs framework, with a deadline of 2030, embodies 17 goals and a total of 169 targets linked to five areas of critical importance, namely: People, Planet, Prosperity, Peace, and Partnerships. The goals comprise: 1) End poverty in all forms;2) End hunger by promoting sustainable agriculture; 3) Healthy lives and wellbeing for all; 4) Quality and equitable education; 5) Gender equality and empowerment; 6) Clean water and sanitation; 7) Sustainable energy for all; 8) Sustainable economic growth; 9) Sustainable industrial growth; 10) Reduce inequality within and between nations; 11) Sustainable shelters and cities; 12) Sustainable production and consumption; 13) Combat climatic change and its impact; 14) Sustainable use of marine resources; 15) Protection of terrestrial ecosystems; 16) Peaceful and inclusive communities; and 17) Global partnerships. Essentially, the SDGs cover the three dimensions of $\mathrm{SD}$, namely: economic growth, social inclusion and environmental protection (Morton et al, 2017). 


\section{$\Lambda$ Macrothink}

Table 1. Global Initiatives, Discourses, and Summits Relevant to SD and ESD

\section{Year Events}

1977 1st Intergovernmental Conference on Environmental Education, Tbilisi, Georgia, 14-26 October - Emphasized the critical role of environmental education in the sound and balanced development of the world's communities with an emphasis on five categories of environmental education, namely: awareness, knowledge, attitudes, skills, and participation.

1987 World Commission on Environment and Development (Brundtland Commission) - Our Common Future (or the Brundtland Report) defined sustainable development and called for the UN General Assembly to transform the report into a UN Programme on Sustainable Development.

1990 World Conference on Education for All, Jomtien, Thailand, 5-9 March Developed the World Declaration on Education for All and the Framework for Action to Meet Basic Learning Needs.

1992 UN Conference on Environment and Development (Rio Summit), Rio de Janeiro, Brazil, 3 - 14 June - Developed the Rio Declaration on Environment and Development and Agenda 21 as well as set out the principles of sustainable development with Chapter 36 of Agenda 21 of the Summit emphasizing the critical role of education, public awareness and training in achieving sustainable development.

2000 World Education Forum, Dakar, Senegal, 26-28 April - Adopted the Dakar Framework for Action on Education for All.

2002 UN World Summit on Sustainable Development (Earth Summit 2002, Rio+10), Johannesburg, South Africa, 26 August - 4 September - Produced the Johannesburg Declaration on Sustainable Development and the Johannesburg Plan of Implementation, which proposed the Decade of Education for Sustainable Development (DESD). This culminated in the December 2002 adoption, at the $57^{\text {th }}$ Session of the UN General Assembly, of a resolution (Resolution 57/254) to commence the UN Decade of Education for Sustainable Development (2005-2014) from January 2005.

2012 UN Conference on Sustainable Development (Rio+20), Rio de Janeiro, Brazil, 20 - 22 June - Produced the document, The Future We Want, which stresses, inter alia, international community's resolve to "promote education for sustainable development and to integrate sustainable development more actively into education beyond the Decade of Education for Sustainable Development" 
(The Future We Want, para 233).

2012 Higher Education Sustainability Initiative (HESI) - A partnership initiative created in 2012 in the run-up to Rio +20 with a view to providing "higher education institutions with a unique interface between higher education, science, and policy making".

2013 Global Action Programme (GAP) on ESD - Endorsed by the $37^{\text {th }}$ session of UNESCO General Assembly as a follow-up to the DESD and with a view to "generate and scale-up ESD and to accelerate progress towards sustainable development"; launched at the UNESCO World Conference on ESD, Nagoya, Japan, November 2014 along with the Final Report of the DESD.

2014 Global Education for All Meeting, Muscat, Oman, 12-14 May - Developed the Muscat Agreement.

2014 UNESCO World Conference on ESD, Nagoya, Japan, November - Launched the GAP on ESD.

2015 World Education Forum 2015, Incheon, Republic of Korea, 19-22 May Adopted the Incheon Declaration for Education 2030 and Framework for Action for the Implementation of SDG4.

Although the global goals are essentially interconnected and interdependent, Mohanty and Dash (2018) have identified a closer link between SDG4 on equitable quality education and the effective implementation of SDG16, which focuses on peace, justice, and strong institutions. This underscores the central position of SDG4 - which envisages ensuring inclusive and equitable quality education and promoting lifelong learning opportunities for all - in fostering SD.

In the context of the International Education Framework and the 2030 Agenda, SDG4 embodies 10 targets, comprising 7 outcome targets and 3 means of implementation (Global Campaign for Education, 2019). The outcome targets comprise: universal primary and secondary education; early childhood development and universal pre-primary education; equal access to technical/vocational and higher education; relevant skills for decent work; gender equality and inclusion; universal youth literacy; and education for sustainable development and global citizenship.

The means of implementation comprise: Effective learning environments; Scholarships; and Teachers and educators. As a matter of fact and in the context of the 10 targets of SDG 4, the Muscat Agreement of May 2014 affirms that the post-2015 education agenda "should be 
rights-based and reflect a perspective based on equity and inclusion, with particular attention to gender equality and to overcoming all forms of discrimination in and through education" (UNESCO, 2014a, para.8).

It is worth mentioning at this juncture that, prior to the adoption in 2015 of the 2030 Agenda by UN member states, the African Union had crafted, specifically in 2013, an African-driven agenda - Agenda 2063: The Africa We Want - that outlined what the African continent should look like in 50 years based on the pillars of wealth generation, regional integration, and attainment of a peaceful society (The Sustainable Development Goals Center for Africa and Sustainable Development Solutions Network, 2018). While the SDGs 2030 Agenda include 17 goals and 169 targets, the African Agenda 2063 include 20 goals and 174 targets.

\section{Concepts of Sustainable Development and Sustainable Education}

Sustainability is a paradigm for thinking about our future in which environmental, societal and economic considerations are balanced in the pursuit of improved quality of life and development (Mohanty \& Dash, 2018). It refers generally to the capacity for the biosphere and human civilization to coexist (Wikipedia) and is also "a holistic approach that considers ecological, social and economic dimensions, recognizing that all must be considered together to find lasting prosperity" (University of Alberta).

Within this perspective, sustainability stands on three pedestals - environmental, economic, and social sustainability. The idea of sustainability, according to global footprints (www.globalfootprints.org/sustainability) stems from the concept of sustainable development which became common language at the World's first Earth Summit in Rio in 1992. Obasi (2019) claims that the word sustainable came to global limelight after its use in a publication titled: Limits to Growth by the Club of Rome in 1972, while the term 'sustainable development' was first introduced by the International Union for the Conservation of Nature in 1980 (Corridi, 2008).

The SD agenda essentially embodies the Education for All (EFA) paradigm. It has been posited that the commitment to 'full and equal opportunities for education for all' actually goes back to UNESCO's constitution (Uvalic-Trumbic \& Daniel, 2016, p. 4). Education, therefore, is not only a key dimension of 'population quality' (Brundtland Commission, 1987) but is also a critical element "for promoting sustainable development and improving the capacity of the people to address environment and development issues" (UN Sustainable Development, 1992, Chapter 36, para 36.3).

The Brundtland Commission (1987) defines SD as development that meets the needs of the present without compromising the ability of future generations to meet their own needs. SD, in the context of this paper, however, emphasizes a developmental paradigm shift that de-emphasizes undue focus on economic growth and human development while conceptualizing development from the sustainability lens in the context of a 'triple bottom line' philosophy that integrates the economic, environmental, and social contexts of development.

The concept of sustainable education (SE), on its part, represents renewable resources to be geared towards the acquisition of key competencies of the $21^{\text {st }}$ century including sustainable 
lifestyles, work and habitat (Bronden, 2015, cited in Mohanty \& Dash, 2018). It implies four descriptors - educational policy and practice which is sustaining, tenable, healthy and durable (Sterling, 2008) - and embodies two concepts: sustainability of education and education for sustainable development (ESD).

Since 'sustainability' indicates the need for a change of educational paradigm as a whole (Wade, 2008), sustainability of education should necessarily emphasize transformational shifts in educational approaches that sufficiently accommodate sustainability perspectives. The concept of education for sustainable development (ESD), according to Gokool-Ramdoo and Rumjaun (2017), can be traced back to 1972 when the United Nation's Conference on Human Environment emphasized the role of education as a means of addressing the problems of human environment. ESD, as addressed in Target 4.7 of SDG4, is related to development education, which, in the words of O'Flaherty and Liddy (2018), "is conceptualized in terms of the inclusion of global development topics in education, reflective of a particular educative focus" (p. 1033). It is about lifelong learning, and is an integral part of quality education (UNESCO, 2014b). It serves as one of the key answers to dealing with sustainability (Boeve-de Pauw et al, 2015) and achieves its purpose by transforming society (UNESCO, 2014b). It also essentially represents " a catch-all term for educational approaches to issues such as climate change, unsustainable living and growing inequity in access to natural resources" (Madsen, 2013, p. 3771) with the underlying idea of "providing opportunities for each individual to acquire the contextually and culturally relevant knowledge, skills, attitudes and values necessary to shape a sustainable future" (Gokool-Ramdoo \& Rumjaun, 2017, p. 75), promoting "competences such as critical thinking, imagining future scenarios, making decisions and solving problems in a collaborative way" (Westermann \& Venegas Muggli, 2017, p. 189) as well as empowering "students with sustainability competences through a holistic interdisciplinary perspective of content and pluralistic learner-centered democratic teaching strategies" (Boeve-de Pauw et al, 2015, p. 15694).

There are three known approaches to ESD - education about sustainable development, education for sustainable development, and critical education towards sustainable development (Shohel \& Howes, 2011, cited in Chinedu et al, 2018). These approaches certainly requires innovative pedagogical overtures in order to achieve the fundamental objectives of ESD. According to Westermann and Venegas Muggli (2017, p. 189), "ESD requires participatory teaching and learning approaches in order to motivate teachers and empower learners to change their behavior and take action to achieve sustainable development".

\section{The Concept of Open and Distance Learning (ODL)}

The fundamental objective of ODL is the provision of education for all. It, therefore, serves as "an inclusive instructional platform that caters for anyone who desires good education but constrained by factors such as distance, age, time, occupation and other circumstances to attend campus-based education" (Ikegulu \& Oranusi, 2014, p. 167). For this reason ODL serves as a veritable platform for implementing lifelong learning. 
Traditionally, the ODL form of education provision has been applied to all levels of education including vocational and non-formal education. It has been posited that ODL education for primary and secondary schools is an important method of expanding educational opportunities to the semi-adult and adult population particularly in developing countries (Ghosh et al, 2012) aside from serving as a vehicle for providing both in-school and out-of-school programmes (UNESCO, 2002). However, it is clear that ODL has developed a much more engaging affinity with the post-secondary or tertiary level of education in recent times. Indeed, there are more distance learning courses offered at the tertiary level than at any other (UNESCO, 2002). Jegede (2016) notes that as far back as 1920 certain characteristics of ODL took firm grounds in tertiary education worldwide. As Bakare (2012) has also rightly argued, distance education "is best suited for the more mature learner who has the capacity to assess his circumstances, make life choices, thus, as a self-directing individual, benefits more from distance education as an active discoverer and constructor of his own learning" (p. 285).

Notably, the term "Open and Distance Learning" has been subjected to a wide variety of conceptualizations and definitions. The Commonwealth of Learning and Asian Development Bank's (1999) publication, Use and Integration of Media in Open and Distance Learning, note that there are many approaches to defining the term with most definitions paying attention to the following characteristics: separation of teacher and learner in time or place, or in both time and place; institutional accreditation; use of mixed-media courseware; two-way communication that allows learners and tutors to interact; possibility of face-to-face meetings; and use of industrialised processes. In this context, open and distance learning has been defined as "a form of instruction by a mode other than the face-to-face method, where there is physical separation between the teacher and the learner and instruction takes place through a variety of media including print and modern ICT" (Jegede, 2016, p. 9).

ODL embodies two distinct concepts - Open Learning and Distance Learning. The concept of open learning is related to the phenomena of flexibility, openness and access irrespective of time, place, age, previous academic qualifications and so on. Thus, open education is underpinned by the philosophy that knowledge should be free and open to use and re-use (Okebukola, 2013). Distance learning or simply distance education emphasizes learner-centredness and is related to a scenario typified by physical separation, in time and place, between teachers and learners. It is, in the words of Biao (2012), "an educational enterprise during which, a facilitator of learning, who is usually separated from the learner by spatial or mental distance, gathers, collates and presents information in a learnable form to one or a group of learners who have accepted the responsibility to learn". For this reason, ODL programmes normally fall somewhere along two continua: the continuum of time and the continuum of place (Commonwealth of Learning and Asian Development Bank, 1999).

\section{Concept of Lifelong Learning}

Lifelong learning (LLL) or continuous learning translates the acquisition and development of knowledge to a process that is essentially an integral part of living. For traditional learning, the learning process is, in the words of Soni $(2012$, p. 1), "dichotomized into a place and time to acquire knowledge (school) and a place and time to apply knowledge (the workplace)", while 


\section{Ml Macrothink}

LLL, which is knowledge-intensive and fluid (London, 2012), conceptualizes learning as "the lifewide, voluntary and self-motivated pursuit of knowledge for not only personal but professional reasons as well” (Ates \& Alsal, 2012, p. 4092).

LLL is both a need and a principle for education and learning systems worldwide (Torres, 2003). Soni (2012) identifies four characteristics which transform education and training into LLL. These are: the integration of both formal and non-formal/informal learning; self-motivated learning; self-funded learning; and a commitment to universal participation in education and training. Thus, LLL "implies an inclusive education and learning model that includes all - children, youth and adults, both as learners and as educators" (Torres, 2003, p. 20). It recognizes that learning is not confined to childhood or the classroom, but takes place throughout life and in a variety of situations (Ates \& Alsal, 2012), the fundamental goal being to enable "learners to acquire more of the new skills demanded by the knowledge economy as well as more traditional academic skills" (Soni, 2012, p. 5). Aspin and Chapman (2001) also point out,

"Lifelong learning offers people the opportunity to bring up to date their knowledge of activities which they had either previously laid aside or always wanted to try but were unable; to try out activities and pursuits that they had previously imagined were outside their time or competence; or to work at extending their intellectual horizons by seeking to understand and master some of the recent cognitive advances, that have transformed their worlds" (p. 2).

LLL, according to Torres (2003), acknowledges two inter-related facts - that learning is lifelong (not confined to a particular period in life), and that learning is lifewide (not confined to school and to schooling). From a purely theoretical perspective, Kanwar et al (2013), cited in Balasubramanian et al (2017), describe LLL as an integration of three theoretical perspectives: pedagogy (theory of learning), andragogy (theory of self-directed learning), and heutagogy (theory of self-determined learning); the heutagogical approach being, according to Blaschke (2012, p.60) citing Canning (2010), "a progression from pedagogy to andragogy to heutagogy, with learners likewise progressing in maturity and autonomy" (cited in Balasubramanian et al, 2017, p. 2).

\section{Nigerian Education Sector: Patterns and Trends}

Trends at the global, regional and national levels reveal slow progress, in a number of cases, towards achieving the targets of SDG4. In 2016, 263 million children, adolescents and youth were out of school, representing nearly one-fifth of the global population of this age group (UNESCO Institute for Statistics, 2018). Of these, a whopping 96.9 million belong to sub-Saharan Africa as against 95.8 million, 6.2 million, and 1.0 million recorded by Southern Asia, Europe and Northern America, and Central Asia respectively.

Sub-Saharan Africa, according to the United Nations (2018), also faces the dilemma of providing basic education to 444 million children between the ages of 3 and 15 in 2030, which represents 2.6 times the numbers enrolled today. The Nigerian situation is by no means fair. Out of the 20 million out-of-school children worldwide, Nigeria has the highest number with about 12.7 million out-of-school children (FME, n.d.). The Nigeria Digest of Education 
Statistics for 2014-2016 (FME, 2017) shows that the total primary school enrolments for the 2011-2012 and the 2015-2016 sessions stood at 24,893,442 and 25,591,181 respectively with the total number of primary schools peaking at 92,084 and 96,901 respectively. For the same sessions, junior secondary school enrolments (the last 3 years of the 9-year Basic Education programme in Nigeria) stood at 6,910,630 and 5,838,987 with 21,784 and 32,833 schools as against enrolments of 4,934,722 and 4,475,309 at the senior secondary school levels with the number of senior secondary schools peaking at 21,784 and 21,688 respectively. Under the Nigerian Mass Literacy, Adult and Non-formal Education initiative, there were, in the 2014-15 period, a total of 21,111 adult literacy centres with a national enrolment figure of 2,924,853 (FME, 2017).

In relation to tertiary education, there are today a total of 174 universities in Nigeria, up from 146 and 129 recorded for 2017 and 2013 respectively. In the ODL realm, there are currently one single-mode ODL University - the National Open University of Nigeria (NOUN) - and 11 dual-mode conventional universities with distance learning centres recognized by the National Universities Commission (NUC). According to the National Universities Commission (2017), total student enrolment at NOUN in 2017 stood at 78,805 and 391,956 for the post-graduate and undergraduate levels respectively.

From the perspective of the 2018 Africa SDG Index and Dashboard (The Sustainable Development Goals Center for Africa and Sustainable Development Solutions Network, 2018), which ranks 51 African states according to 97 indicators across all 17 SDGs, Nigeria occupies the $39^{\text {th }}$ position with a percentage point of 48.0 as against the $66.1,65.9,62.0$, and 54.7 points recorded by Morocco (which leads the continent), Tunisia, Ghana, and Tanzania respectively. The 2018 Africa SDG Dashboard shows that no African country is recording achievement in respect of SDG4 (Quality education). Nigeria fails to record any achievement in relation to the 17 SDGs while showing just moderate progress in SDG 6 (Clean water and sanitation) and SDG 13 (Climate action).

\section{ODL and Lifelong Learning: Roles and Values in Education}

There are strong indicators that open and distance learning is becoming more central to the education policy of many countries (UNESCO, 2002, p.43). As emphasized in the Framework for Action of the 2015 World Education Forum, education is essentially at the heart of the 2030 Agenda for SD and is not only "essential for the success of all SDGs" but can also "accelerate progress towards the achievement of all of the SDGs" (UNESCO, 2015, para 4). Both formal and non-formal education have also been found to be indispensable to changing people's attitudes and for "achieving environmental and ethical awareness, values and attitudes, skills and behavior consistent with sustainable development and for effective public participation in decision-making" (UN Sustainable Development, 1992, Chapter 36, para 36.3).

The potential of ODL system include the potential: to ameliorate the problem of access (Okojie, 2013); to generate new patterns of teaching and learning as well as serve as a vehicle for innovation in mainstream education (Ghosh et al, 2012); to overcome problems of physical distance for learners in remote locations and for geographically-separated learners and teachers (Commonwealth of Learning/Asian Development Bank, 1999); to serve as a strategic vehicle 
for expansive and comprehensive development through enhanced access to education and training (Jegede, 2016); and to provide, for learners, opportunities for learning and qualification and, for employers, the possibility of organizing learning and professional development in the workplace (UNESCO, 2002).

The essence of LLL is supported by the rapid shifts in demographics, the progressive shifts in socio-economic profiles and the transformative transition from an industrial society to a society driven by technology and information. The role of LLL should be viewed, according to Ates and Alsal (2012), "in the overall goal of improving societal and individual well-being, to take-up of adult learning opportunities which are closely related to initial levels of educational attainment, and reducing inequalities" (p. 4094). The purpose, therefore, should be to engender radical changes in values, conceptualization and attitudes towards issues of development, environment and socio-cultural transformation. According to Bangay (2016, p. 5), "Education's ultimate contribution to sustainable development will come through both individual and societal behavior change - strengthening environmental resilience, and inculcating climate change awareness".

Lifelong learning, in Leyden's (2019) words, preserves an individual's desire to obtain new knowledge outside of the formal education system. Aspin and Chapman (2001) argue that people can have their view of the world and capacity for rational choice continually expanded and transformed by the educational experiences and cognitive achievements offered by lifelong learning. The authors also identify three elements in lifelong learning, which they describe as the triadic nature of lifelong learning for: economic progress and development; personal development and fulfilment; and social inclusiveness and democratic understanding.

\section{Challenges and Opportunities}

The World Conference on Education for All (WCEFA) has been widely recognized as a monumental milestone in international discourse on education. The conference, which culminated in the adoption of the World Declaration on Education for All and the Framework for Action to Meet Basic Learning Needs, reaffirmed the right of all people to education and proclaimed the importance of a renewed commitment and an expanded vision that encompasses: universalizing access and promoting equity; focusing on learning; broadening the means and scope of basic education; enhancing the environment for learning; and strengthening partnerships (WCEFA Inter-Agency Commission, 1990). The conference also implicitly proclaimed that "the responsibility for providing EFA cannot be left to market mechanisms at a time when the market seems to have gained a monopoly in organizing and regulating social and economic life" (Hallak, 1991, p. 19).

In spite of the tremendous amount of recent dialogues on education and SD, many challenges still remain. The main challenge is the progressive increase in population, while the resources for sustaining the burgeoning population remains finite. In Nigeria, one of the greatest challenges comes from institutional flaws in terms of approaches, policy thrust, decision making, and official conceptualization of the role and value of ODL and LLL. One emerging problem in relation to ODL in Nigeria is the stifling of expansion of access in the name of cost-effectiveness, scarce resources and the need to prioritize. 
Literature reveal other problems such as "mounting debt burdens, the threat of economic stagnation and decline, rapid population growth, widening economic disparities among and within nations, war, occupation, civil strife, violent crime, the preventable deaths of millions of children and widespread environmental degradation" (UNESCO, 1994, preamble).

As highlighted in the Sustainable Development Goals Center for Africa and Sustainable Development Solutions Network's (2018) report, key challenges in implementing SDGs include: lack of adequate dedicated financial resources, lack of good quality data, lack of policy coherence and coordination across levels of government, lack of awareness among the civil society, lack of capacity in the civil service, lack of effective linkages between policy planning and budgeting at the central/federal level of government, and lack of political support. Hallak (1991) identifies five categories of obstacles to achieving EFA - political factors, economic/financial factors, lack of adequate demand for education, weak capacity, in managerial terms, for implementing the broad concept of EFA, and heavy inertia within the existing education systems. Citing Kumar et al (2016), Jaiyesimi (2016) identifies financial, maintaining peace, measuring progress and accountability as four major challenges that need to be addressed for achieving SDGs in Africa.

Given the critical role data play in policy development and the ability to adequately respond to developmental and other challenges, the issue of data availability represents a monumental challenge to achieving SDGs and it appears that the problem is noticeably pervasive in Africa. Many countries in Africa lack the capacity to collect, manage, and report on demographic, social, economic, and environmental data with National Statistical Offices in Africa facing "the challenge of high turnover rates making it difficult to develop in-house expertise, to apply international statistical standards, and to employ new technologies to collect and disseminate statistics and information" (The Sustainable Development Goals Center for Africa and Sustainable Development Solutions Network, 2018, p. 5). For example, in the UNESCO Global SDG4 Data Book for 2019, no data was available for Nigeria in respect of all the SDG Indicators for the period from 2010 to 2018 with the exception of SDG Indicator 4.2.1 where data was available for only 2017 . This challenge appears to be linked to inadequate resourcing of statistical tools, inadequate funding, and the fact that official engagements with achieving SDGs appears to be overshadowed by 'political signaling' with a disconnect between the political realm and agencies designated for driving SDGs.

Both ODL and LLL offer significant opportunities for achieving the SDGs, particularly SDG4. Not only can the two phenomena foster the integration of SD into the education and training spheres, but they can act as a vehicle for diffusing SD principles and practices into communities. Given that the pivotal role of lifelong learning within the vision of human capability expansion makes building the learning society a goal of paramount importance (Ahmed, 2014), understanding lifelong learning requires analyzing the societal, cultural, and organizational trends that drive continuous learning opportunities and behavior (London, 2012).

\section{Conclusions}

This paper explored perspectives and ideologies on the key issues of lifelong learning, ODL, 
SD, ESD, and the Global Goals in an attempt to understand the essence of ODL and lifelong learning in achieving the SDGs within the context of the Nigerian education realm. The study revealed that education in all its forms - including the ODL and the lifelong forms of education provision - is not only essential to achieving the SDGs but is also a veritable platform for transferring enduring values, attitudes, knowledge and skills for promoting economic, social and environmental sustainability. An important finding is that promoting SD through education requires the integration of a 'triple bottom line' philosophy that encapsulates the three dimensions of sustainability - social, environmental and economic sustainability.

An important conclusion that can be drawn from the perspectives and trends revealed in the study is that in spite of the existence of a number of programmes, projects, and policies for the massification of education, Nigeria is still a long way to achieving the SDGs. Within this perspective, understanding ODL and lifelong learning and a critical analysis of the socio-economic and environmental dimensions of sustainable education are critical to moving forward.

\section{Suggestions}

Based on the trends and perspectives revealed in the present study, the following suggestions are necessary for mainstreaming ODL and lifelong learning for the purpose of achieving the SDGs, particularly SDG4, in Nigeria:

- The philosophies and principles of sustainable development should be integrated in education and training at all levels and education systems should be aligned with the elements and challenges of sustainability. This will entail a review of curricula to reflect SD needs.

- Consistent with Article 8 of the World Declaration on EFA 1990, a supportive policy and institutional framework and a strong political commitment are central elements. However, as corroborated by Mohanty and Dash (2018), policy instruments or technological solutions may not be enough as behavioural change and public awareness, driven through education, training and capacity building, are very crucial for SD.

- Applicable constitutional provisions on education rights should be strengthened by making them justiciable and legally enforceable.

- Expansion of education and training facilities with a view to fostering and improving knowledge and skills relating to sustainable development.

- Opportunities for LLL should be packaged in the context of a range of community initiatives with a deliberate policy that integrates local development needs and socio-cultural realities in learning. With this perspective, government attitudes and actions should migrate to the prioritization of non-formal education as a key ingredient of LLL.

- Need for multi-sectorial partnerships that emphasize the economic, social, environmental, political, and legal dimensions of access to education. This will involve the three critical elements of People, Planet, and Prosperity. 


\section{Macrothink Institute ${ }^{\mathrm{TM}}$}

- Greater emphasis on the learning needs of the adult population and with a focus on women and youth in the society. This will require a radical paradigm shift from the increasing sectorization of education in Nigeria. It will also require an atmosphere in which education is seen not only as a social element but also as an integral part of the socio-economic policy framework of the country.

- Expand ODL and LLL facilities with an emphasis on the provision of free massive online open courses (MOOCs) designed to impart SD competencies.

- The concept of education should be broadened and conceptualized within the framework of the socio-cultural, environmental, and political realities in the society. This will require realigning the functional elements of Nigerian education system to imbibe the philosophies of education for SD and education about SD.

- Massive use of the tools of digital technologies to "massify" ESD principles and philosophies.

\section{Acknowledgements}

This paper was presented at the $1^{\text {st }}$ International Conference of the Faculty of Education, National Open University of Nigeria (NOUN), NOUN Headquarters, Abuja, Nigeria, 23-27 September, 2019. The author acknowledges the invaluable review comments provided by Dr. Bamikole Ogunleye, Chair of the Conference's Syndicate 3, Dr. Tessy Angba, co-chair, and Dr. J. Oluwadamilare Amusa (rapporteur). The present paper essentially integrates those important comments.

\section{References}

Ahmed, M. (2014). Lifelong Learning in a Learning Society: Are Community Learning Centres the Vehicle? In: Education, Learning, Training: Critical Issues for Development. (pp. 102-125). Geneva: Graduate Institute Publications. https://doi.org/10.1163/9789004281158_007

Aspin, D., \& Chapman, J. (2001). Lifelong Learning: Concepts, Theories and Values. Paper presented at SCUTREA 31 $1^{\text {st }}$ Annual Conference, University of East London, 3-5 July 2001.

Ates, H., \& Alsal, K. (2012). The importance of lifelong learning has been increasing. Procedia-Social and Behavioral Sciences 46(2012), 4092-4096. https://doi.org/10.1016/j.sbspro.2012.06.205

Bakare, T. V. (2012). Access to Higher Education for National Development in Nigeria: Distance Education to the Rescue. Journal of International Education Research, 8(3), 283-294. https://doi.org/10.19030/jier.v8i3.7110

Balasubramanian, K., Carr, A., \& Onyango, J. (2017). Structure, Function and Impact of Lifelong Learning Using ICT and ODL. Keynote speech, ODLAA Conference, Melbourne, February 6, 2017. 


\section{Macrothink}

International Journal of Learning and Development

ISSN 2164-4063 2020, Vol. 10, No. 1

Bangay, C. (2016). Protecting the Future: The Role of School Education in Sustainable Development - An Indian Case Study. International Journal of Development Education \& Global Learning, 8(1), 5-19. https://doi.org/10.18546/IJDEGL.8.1.02

Biao, I. (2012). Open and Distance Learning: Achievements and Challenges in a Developing Sub- Educational Sector in Africa. In: I. Biao (Ed.), Distance Education. https://doi.org/10.5772/48080

Boeve-de Pauw, J., Gericke, N., Olsson, D., Berglund, T. (2015). The Effectiveness of Education for Sustainable Development. Sustainability 2015, 7, 15693-15717. https://doi.org/10.3390/su71115693

Brundtland Commission (1987). Our Common Future. Report of the World Commission on Environment and Development. Retrieved from https://sustainabledevelopment.un.org/ content/documents/5987our-common- future.pdf/

Chinedu, C. C., Wan Mohammed, W. A., \& Ajah, A.O. (2018). A Systematic Review on Education for Sustainable Development: Enhancing TVE Teacher Training Programme. Journal of Technical Education and Training, 10(1), 109-125. https://doi.org/10.30880/jtet.2018.10.01.009

Commonwealth of Learning/Asian Development Bank (1999). Use and Integration of Media in Open and Distance Learning - Training Toolkit. Canada, BC: Commonwealth of Learning

Corridi, J. (2008). Editorial. In: J. Corridi (Ed.), Policy and Practice: A Development Education Review. Lisbon: Centre for Global Education.

FME (2017). Nigeria Digest of Education Statistics (2014-2016). Abuja: Federal Ministry of Education.

FME (n.d.). Education for Change: A Ministerial Strategic Plan (2018-2022). Abuja: Federal Ministry of Education.

Ghosh, S., Nath, J., Agarwal, S., Nath, A. (2012). Open and Distance Learning (ODL) Education System: Past, Present and Future - A Systematic Study of an Alternative Education System. Journal of Global Research in Computer Science, 3(4), 53-57.

Global Campaign for Education (2019). SDG4's 10 Targets. Retrieved from https://www.campaignforeducation.org/en/who-we-are/the-international-educationframework-2/the-sustainable-development-goal-4/sdg4s-10-targets/?gclid=_VuMyT4wlVC5z tCh0QpAlmEAAYAyAAEglOLPD_BwE/EAlalQobChMI6f (August 12, 2019).

Gokool-Ramdoo, S., \& Rumjaun, A. B. (2017). Education for Sustainable Development: Connecting the Dots for Sustainability. Journal of Learning for Development, 4(1), 72-89.

Goodier, S. (2017). Tracking the Money for Open Educational Resources in South African Basic Education: What We Don't Know. The International Review of Research in Open and Distributed Learning, 18(4). https://doi.org/10.19173/irrodl.v18i4.2990

Hallak, J. (1991). Education for All: High Expectations or False Hopes? Paris: IIEP. 


\section{I Macrothink}

International Journal of Learning and Development

ISSN 2164-4063

2020, Vol. 10, No. 1

Ikegulu, B. \& Oranusi, S. (2014). Distance and Open Learning in Nigeria: Progress, Concerns and Prospects. Journal of Education and Practice, 5(35), 167-171.

Jaiyesimi, R. (2016). The Challenge of Implementing the Sustainable Development Goals in Africa: The Way Forward. African Journal of Reproductive Health, 20(3), 13-18. https://doi.org/10.29063/ajrh2016/v20i3.1

Jegede, O. (2016). Open and Distance Learning Practices in Nigerian Higher Institutions of Learning. Keynote address at the $3^{\text {rd }}$ University of Ibadan Annual Distance Learning Centre Distinguished Lecture and Stakeholders' Forum held at the International Conference Centre, University of Ibadan, 14-15 July, 2016.

Leyden, A. (2019). 10 Simple Ways to Engage in Lifelong Learning. Retrieved from www.teachthought.com/learning/10-simple-ways-to-engage-in-lifelong-learning/ (February 2, 2019).

London, M. (2012). Lifelong Learning: Introduction. In: M. London (Ed.), Oxford Handbook of Lifelong Learning. UK: Oxford University Press. https://doi.org/10.1093/oxfordhb/9780199928286.013.0035

Madsen, K. D. (2013). Unfolding Education for Sustainable Development as Didactic Thinking and Practice. Sustainability 2013, 5, 3771-3782. https://doi.org/10.3390/su5093771

Mohanty, A., \& Dash, D. (2018). Education for Sustainable Development: A Conceptual Model of Sustainable Education for India. International Journal of Development and Sustainability, 7(9), 2242-2255.

Morton, S., Pencheon, D., \& Squires, N. (2017). Sustainable Development Goals (SDGs) and their Implementation. British Medical Bulletin, 2017 (124), 81-90. http://dx.doi.org/10.1093/bmb/ldx031

National Universities Commission (2017). Nigerian University System Statistical Digest 2017. Abuja: NUC.

Obasi, I. N. (2019). Growth and Sustainability in the $21^{\text {st }}$ Century. Presentation at the 2019 National Conference of the Institute of Management Consultants, 15 August, Abuja, Nigeria.

O'Flaherty, J., Liddy, M. (2018). The Impact of Development Education and Education for Sustainable Development Interventions: A Synthesis of the Research. Environmental Education Research, 24(7), 1031-1049. https://doi.org/10.1080/13504622.2017.1392484.

Okebukola, P. (2013). Open Education and the March to 2020: Can Nigeria Make It? Text of $2^{\text {nd }}$ Pre-Convocation Lecture, National Open University of Nigeria, 18 January, 2013.

Okojie, J. (2013). Strengthening Institutional Capacity for the Mainstreaming of ODL. Keynote address at the $7^{\text {th }}$ Pan-Commonwealth Forum (PCF7) on Open and Distance Learning, International Conference Centre, Abuja, Nigeria, 2-6 December, 2013. 
OSSAP-MDGs (2015). Millennium Development Goals: End-point Report 2015. Abuja, Nigeria: Office of the Senior Special Assistant to the President on the MDGs.

Soni, S. (2012). Lifelong Learning - Education and Training. Proceedings of FIG Working Week 2012, Rome, Italy, 6-10 May 2012. Retrieved from www.fig.net/resources/proceedings/fig_proceedings/Fig2012/

Sterling, S. (2008). Sustainable Education: Towards A Deep Learning Response to Unsustainability. In: J. Corridi (Ed.), Policy and Practice: A Development Education Review. (pp. 63-68). Lisbon: Centre for Global Education.

The Sustainable Development Goals Center for Africa and Sustainable Development Solutions Network (2018). Africa SDG Index and Dashboards Report 2018. Kigali and New York: Sustainable Development Goals Center for Africa and Sustainable Development Solutions Network.

Torres, R. (2003). Lifelong Learning. Stockholm: SIDA.

UNESCO (1994). World Declaration on EFA and Framework for Action to Meet Basic Learning Needs, $3^{\text {rd }}$ Edition. Paris: UNESCO.

UNESCO (2002). Open and Distance Learning - Trends, Policy and Strategy Considerations. Paris: UNESCO.

UNESCO (2014a). The Muscat Agreement: 2014 Global Education for All Meeting (GEM) Final Statement, Muscat, Oman, 12-14 May, 2014.

UNESCO (2014b). Roadmap for Implementing the Global Action Programme on Education for Sustainable Development. Paris: UNESCO.

UNESCO (2015). SDG4 - Education 2030 Framework for Action. Paris: UNESCO.

UNESCO Institute for Statistics (2018). One in Five Children, Adolescents and Youth is out of School. Fact Sheet No. 8, February 2018. Retrieved from https://uis.unesco.org/sites/default/files/documents/fs48-one-five-children-adolescents-youths -out-school-2018-en.pdf

United Nations (2018). Quality Education: Why It Matters. Retrieved from www.un.org/sustainabledevelopment/wp-content/uploads/2018/09/Goal-4.pdf/

United Nations (2012). The Future We Want-Outcome Document of the UN Conference on Sustainable Development. New York: United Nations.

University of Alberta. What is Sustainability? Retrieved from www.mcgill.ca/sustainability/files/sustainability/what-is-sustainability.pdf

UN Sustainable Development (1992). Agenda 21 - United Nations Conference on Environment and Development, Rio de Janeiro, Brazil, 3 to 14 June 1992. 


\section{Macrothink}

International Journal of Learning and Development

ISSN 2164-4063 2020, Vol. 10, No. 1

Uvalic-Trumbic, S., \& Daniel, J. (2016). Sustainable Development Begins with Education. Journal of Learning for Development, 3(3), 3-8.

Wade, R. (2008). Education for Sustainability: Challenges and Opportunities. In: J. Corridi (Ed.), Policy and Practice: A Development Education Review. (pp.30-48). Lisbon: Centre for Global Education.

WCEFA Inter-Agency Commission (1990). Final Report - World Conference on Education for All. New York: WCEFA Inter-Agency Commission.

Westermann, J. W., \& Venegas Muggli, J. I. (2017). Effectiveness of OER Use in First-year Higher Education Students' Mathematical Course Performance: A Case Study. In: C. Hodgkinson-Williams \& P.B. Arinto (Eds.), Adoption and Impact of OER in the Global South (pp. 187-229). https://doi.org/10.5281/zenodo.601203.

Wikipedia. Sustainability. Retrieved from https://en.wikipedia.org/wiki/Sustainability/

Zenelaj, E. (2013). Education for Sustainable Development. European Journal of Sustainable Development, 2(4), 227-232.

\section{Copyright Disclaimer}

Copyright for this article is retained by the author(s), with first publication rights granted to the journal.

This is an open-access article distributed under the terms and conditions of the Creative Commons Attribution license (http://creativecommons.org/licenses/by/4.0/). 